\title{
Historia reciente, género y clase trabajadora
}

Karin Grammático, Mariela Marini y Wanda Wechsler (comps.)

Buenos Aires, Imago Mundi, 126 pp.

\section{(1) Clara Chevalier}

\section{Universidad Nacional Arturo Jauretche}

Desde su título, Historia reciente, género y clase trabajadora nos propone un cruce de tres categorías de diversos orígenes y mucha vigencia en la historiografía actual. El libro no solo presenta dichas categorías sino que propone formas de trabajar con ellas desde el aquí y el ahora. En este sentido, es una caja de herramientas para el/la investigador/a interesado/a en estas temáticas.

Esto quizás se vincule con el hecho de que el libro es fruto del trabajo de las compiladoras en el marco del proyecto de investigación "Experiencias, luchas y memorias de trabajadoras y trabajadores en el pasado reciente argentino", radicado en la Universidad Nacional Arturo Jauretche. En ese ámbito de producción académica, Grammático, directora del equipo, Marini y Wechsler organizaron una serie de conferencias con referentes de las temáticas abordadas en esa propuesta investigativa. Los cinco artículos que componen este libro recuperan - total o parcialmente- lo acontecido en esos encuentros en los que las/os especialistas invitadas/os desplegaron una serie de consideraciones conceptuales, propuestas metodológicas y discusiones que resultan enriquecedoras. Así lo expresan las compiladoras para pensar un problema de investigación en el que dialoguen la clase social y el género en el singular contexto de la historia reciente argentina. Reconociendo la valía de esas intervenciones, Grammático, Marini y Wechsler decidieron armar la presente compilación.

Débora D’Antonio y Ariel Eidelman están a cargo del estudio inicial. "Diálogos y debates en la historia reciente argentina" se pregunta por la existencia de un campo de estudios al que podamos denominar historia reciente. Los/as autores/as -historiadores/ as ambos/as- detectan problemáticas comunes y relevan investigaciones que se reconocen como integrantes de un ámbito común, al tiempo que indagan en las posibles periodizaciones del tiempo presente.
Este panorama general permite afirmar la existencia del campo de la historia reciente al tiempo que pone de manifiesto su notorio dinamismo en los últimos años; potenciado, podemos agregar, por la capacidad de interpelar al gran público.

"Entre generaciones: militancia y transmisión" es una reflexión en torno a la fuente clave de la historia reciente: el testimonio. La clandestinidad condujo a la escasez de fuentes escritas mientras que el carácter traumático de los procesos que estructuran nuestra historia reciente hacen del testimoniar un acto en ocasiones necesario para quienes vivieron esos años. En este apartado, Alejandra Oberti indaga en la particularidad del testimonio como fuente y plantea una forma de trabajarlo. A partir de conceptos delineados por teóricos mayormente europeos, la autora hila una propuesta de análisis que vuelve asible el testimonio como condensación de tiempos, sujetos y sentidos. A las temporalidades superpuestas en el testimonio, que narra desde un momento posterior, experiencias previas, se añade una más: la de el/la investigador/a que se formula preguntas también atravesadas por su época. Hacia el final del artículo, esta propuesta se plasma en el estudio de un testimonio de militancia que hace foco en la maternidad, la afectividad y la vida cotidiana.

La potencialidad de la narración nos lleva al tercer artículo a cargo de Florencia Partenio. En “Género, trabajo y experiencia: perspectivas teóricas-metodológicas para el abordaje de las narrativas biográficas", el relato es tomado como la puerta de entrada por excelencia a la experiencia de las mujeres trabajadoras. Este último concepto, que estructura la reflexión de Partenio, es despojado de ciertos presupuestos de transparencia y totalidad que podemos detectar en algunos de sus usos a partir del recorrido por distintos aportes de teóricas feministas. La experiencia encuentra en las narrativas biográficas la posibilidad de articularse, por lo que es indisociable del lenguaje 
y, por lo tanto, opaca y parcial. Sin embargo, el concepto no pierde su potencia a la hora de dimensionar y valorizar la agencia de las mujeres en el mundo del trabajo. Historizar la experiencia, no darla por sentado, es el desafío para poder dar lugar a otros/ as sujetos/as.

Así como sucede en el capítulo 2, este apartado vuelca el recorrido conceptual por las nociones de experiencia, agencia y narrativas al análisis de relatos de trabajadoras metalúrgicas del conurbano sur. El texto se zambulle en los testimonios para luego volver a salir y repensar desde allí, la potencialidad de la narración en tanto puede albergar la tensión entre los/as "nosotros/as" trabajadores/as metalúrgicos/as con la primera persona singular. A diferencia de otros registros, los relatos tienen espacio para alojar estos pliegues y las mujeres pueden comprender su parte en las historias, valorarlas como propias y asumirse como agentes activas de las mismas.

En "Algunos aportes a la historia de los trabajadores en la década del 70", Federico Lorenz vuelve a los años setenta pero toma un tipo específico de militancia, la sindical, en el mítico Astilleros Astarsa. Así como Oberti plantea desde una perspectiva de género nuevas preguntas a este período, Lorenz hace una lectura crítica de la historiografía al preguntarse por el lugar de los/as trabajadores/as y sus sindicatos en lo que se ha denominado historia reciente. A partir de testimonios, el autor se aproxima a la experiencia de los/as trabajadores/as de esos intensos años previos a la dictadura e indaga en los sentimientos que aparecen en ellos. Pensar los setentas desde los sentimientos es un camino que ha comenzado a explorarse recientemente en la historiografía.

La apuesta de Lorenz finalmente hace foco en otro problema, a la vez político e historiográfico: la relación de Montoneros con el sindicalismo peronista. En esta pregunta que motoriza el artículo (y que lo vuelve sobre la cuestión de la agencia) hay una mirada de lo micro que lleva inscripciones de lo macro. En lo que parece un análisis de caso se pueden repensar grandes polémicas de la historia reciente, como la relación entre Montoneros y el sindicalismo peronista; dos entidades cuya delimitación es - según el historiador-más compleja de lo que comúnmente se ha considerado, o la relación entre la violencia del período 1973-1976 (que enfrentaba muchas veces a sectores del sindicalismo) y la de la dictadura cívico militar.

El cierre queda en manos de Victoria Basualdo, quien en "Militancia y organización obrera de base durante la primera mitad de los años setenta: una aproximación desde la historia oral al caso Alpargatas en Florencio Varela" trabaja sobre una planta emblemática para el territorio en que se implanta la Universidad Nacional Arturo Jauretche. Tomando como fuente el testimonio de distintas/os trabajadoras/es, la autora reflexiona sobre las tensiones que atravesaron al movimiento obrero organizado especialmente entre 1973 y 1976. También aquí la perspectiva de género tiene un lugar. También aquí lo local no es concebido como un todo hermético, sino que contribuye a pensar lo macro; en este caso se trata de los vínculos entre movimiento obrero y organizaciones político-militares, constituido en un doble vector de radicalización política de los/as trabajadores/as y proletarización de los/as militantes.

Historia reciente, género y clase trabajadora bucea en las cualidades y usos de estos tres conceptos tan caros a la historiografía argentina actual. Es posible transitar los artículos que componen el libro tirando de otros hilos conceptuales como experiencia, testimonio, agencia y violencia. Por otro lado, podemos hacer una lectura metodológica del texto y reflexionar sobre las formas de trabajar con el testimonio que aparecen y su puesta en relación o no con otro tipo de fuentes (textos históricos, literarios); o las formas de abordar lo subalterno (los trabajadores, las mujeres). Por último, el libro nos propone recorrer un espacio: el conurbano bonaerense. Desde allí se cuenta la mayoría de las historias que hacen parte de una historia mayor: la historia reciente argentina.

En ese sentido, Historia reciente, género y clase trabajadora no es una sumatoria de artículos, sino una propuesta de acercamiento caleidoscópico a ese campo tan dinámico de la historia reciente desde la clase trabajadora y el género, que nos da un panorama de lo existente al tiempo que abre preguntas y problemas. Por la calidad de los artículos que lo componen y su entrelazamiento, es un libro fundamental para quien desee trabajar estos temas. 